\title{
An Overview of the Present Stability and Performance of EOR-Foam
}

(Gambaran Keseluruhan Kestabilan Semasa dan Prestasi EOR-Buih)

\author{
MOHAMmed Falalu HamZa, CHANDRA MOHAn SinNATHAMBI*, ZULKIFLi MERICAN AlJUNid MERICAN, \\ HASSAN SOLEIMANI \& STEPHEN KARL D.
}

\begin{abstract}
Foam flooding technique, commonly known as foam assisted water alternating gas method (FAWAG) has been identified as an effective chemical enhanced oil recovery (CEOR) technique. The ability of EOR-foam to sweep oil in low permeable zones makes it important displacement fluid in the oil industry. However, extreme reservoir conditions such as temperature, pressure and salinity have detrimental effects on the stability and the overall performance of the EOR-foam. Consequently, understanding foam stability and performance under different conditions is crucial for long term oil field application. This paper discusses the current status of the EOR-foam stability, performance and challenges from laboratory studies to field application perspective. The paper also highlights the knowledge gaps which require further research for successful field application.
\end{abstract}

Keywords: EOR-foam; foam application; foams performance; foam stability

\section{ABSTRAK}

Teknik banjir buih, biasanya dikenali sebagai kaedah air berselang-seli gas berbantu buih (FAWAG) telah dikenal pasti sebagai satu teknik pemulihan (CEOR) minyak tertingkat kimia yang berkesan. Keupayaan EOR-buih untuk menyapu minyak di zon rendah boleh telap menjadikan ia cecair anjakan penting dalam industri minyak. Walau bagaimanapun, keadaan melampau takungan seperti suhu, tekanan dan kemasinan mempunyai kesan yang memudaratkan terhadap kestabilan dan prestasi keseluruhan EOR-buih itu. Oleh yang demikian, kefahaman tentang kestabilan buih dan prestasi di bawah keadaan yang berbeza adalah penting untuk jangka masa panjang bidang aplikasi minyak. Kertas ini membincangkan status semasa kestabilan EOR-buih, prestasi serta cabaran daripada ujian makmal bidang kepada perspektif aplikasi lapangan. Kertas ini juga menyerlahkan jurang pengetahuan yang memerlukan kajian lanjut untuk aplikasi lapangan ini berjaya.

Kata kunci: Aplikasi buih; EOR-buih; kestabilan buih; prestasi buih

\section{INTRODUCTION}

Tertiary oil recovery, alternatively known as enhanced oil recovery (EOR) method was developed to further increase oil production after exhausting primary and secondary methods (Alvarado \& Manrique 2010; Tunio et al. 2011; Tzimas et al. 2005). The EOR techniques involve the injection of specific fluids by any method to displace oil toward producer wells (Hou et al. 2016; Nagy et al. 2015; Shedid 2015; Verma 2015). The injected fluids promote the sweep efficiency by altering the reservoir rock/fluid or fluid/fluid phase properties (Nagy et al. 2015; Touray 2013;). Example of EOR injection techniques involve polymer flooding, surfactant flooding, alkali-surfactantpolymer flooding (ASP), steam flooding, microbial flooding and water alternating gas injection (WAG). Among these processes, water alternating gas (WAG) method has been widely recognized and successfully utilized because of its ability to tackle early gas breakthrough (Hamza et al. 2016; Nangacovié 2012; Tunio et al. 2012). However, recent technology utilizes the applications of foams to assist the WAG method and is called foam assisted water alternating gas method (FAWAG). The FAWAG method reduces the gas mobility as well as minimizes the production of gas cap (Ahmadi et al. 2015). However, foam behaviour and stability at higher temperature and in contact with oil remain a challenge in oil field, as a result, understanding foam behaviour in oil contact under a harsh reservoir conditions (higher temperature) is important. The stability of foam could be improved by modifying the properties of foaming agents (EOR-surfactants) using either nanoparticles or polymers or sometimes the mixture of both (Shedid 2015). Nanoparticles have greater adsorption energy, which enable them to be irreversibly adsorbed to the fluid/fluid interface and increase foam stability (Worthen et al. 2014). Similarly, by incorporating viscoelastic polymers to the EOR-surfactant solution, the thermal and shear resistance of EOR-foam could also be improved, especially when attractive interactions are formed between their charges (Xue et al. 2016). In this paper, a literature survey on the stability and performance of EORfoam has been conducted and various factors responsible for its instability have been outlined and discussed, and measures to resolve these issues are also detailed. 


\section{EOR-FOAM}

EOR-foam was first introduced by Bond and Helbrook in 1958 as a mobility control (Salehi et al.2014). Foam is generated using EOR-surfactants (Farzaneh \& Sohrabi 2013; Nezhad et al. 2013). EOR-surfactants are classified into anionic (Sodium dodecyl benzene sulfonate- $\mathrm{CH}_{3}\left(\mathrm{CH}_{2}\right)_{11} \mathrm{C}_{6} \mathrm{H}_{4} \mathrm{SO}_{3}$ $\mathrm{Na}^{+}$), nonionic (Ethyleneoxy- $\mathrm{C}_{\mathrm{n}} \mathrm{H}_{2 \mathrm{n}+1}\left(\mathrm{OCH}_{2} \mathrm{CH}_{2}\right)$ $\mathrm{OH}$ ), cationic (Trimethyldodecylammoniumchloride$\mathrm{C}_{12} \mathrm{H}_{25} \mathrm{~N}^{+}\left(\mathrm{CH}_{3}\right)_{3} \mathrm{Cl}^{-}$) and amphoteric (Lauramidopropyl betain- $\mathrm{C}_{11} \mathrm{H}_{23} \mathrm{CONH}\left(\mathrm{CH}_{2}\right)_{3} \mathrm{~N}^{+}\left(\mathrm{CH}_{2}\right) \mathrm{CH}_{2} \mathrm{COO}^{-}$) (Schramm 2000). Usually, the dissolved gas in a surfactant solution forms the foam as the gas moves from lower to higher permeable regions in the porous media (Ahmadi \& Sheng 2016; Shabib-Asl et al. 2014). Generally, there are two ways to generate EOR-foam, either by alternating injection of surfactant solution and gas or by simultaneous injecting gas into the lower region and surfactant solution into the upper region (Tunio et al. 2012). The application of foam in EOR has been increasingly studied and demonstrates good effect for sweep conformance and oil recovery (Kapetas et al. 2016; Talebian et al. 2015). For successful utilization of EOR-foam in oil fields, its stability is one of the fundamental requirements. The instability of EORfoam is mainly due to decrease in the viscosity of foaming solution, precipitation and decomposition of foaming agents due to increase in temperature, diffusion of gasses through the foam film due to increase in kinetic energy, foam/oil contact (oil acts as defoamer) (Tyrode et al. 2003).

However, many additives like nanoparticles and polymers, have been reported to improve foam rheological properties and thermal stability in contact with the oil (Sun et al.2015). The action mechanisms of nanoparticles and polymers have been explained in a separate section in this paper. Furthermore, the performance of these additives in improving foam thermal stability could be evaluated by understanding various stability coefficients which include the entering coefficient (E), spreading coefficient (S), bridging coefficient (B), lamella number (L) as well as pseudo-emulsion film. These can be predicted according to the expressions given below (Sun et al. 2015).

Entering coefficient (E)

$$
\left(\boldsymbol{\gamma}_{\mathrm{gw}}+\boldsymbol{\gamma}_{\mathrm{ow}}-\boldsymbol{\gamma}_{\mathrm{og}}\right)
$$

Spreading coefficient (S)

$$
\left(\boldsymbol{\gamma}_{\mathrm{gw}}-\boldsymbol{\gamma}_{\mathrm{ow}}-\boldsymbol{\gamma}_{\mathrm{og}}\right)
$$

Bridging coefficient (B)

Lamella No. (L)

$$
\left(\boldsymbol{\gamma}_{\mathrm{gw}}{ }^{2}+\boldsymbol{\gamma}_{\mathrm{ow}}{ }^{2}-\boldsymbol{\gamma}_{\mathrm{og}}{ }^{2}\right)
$$$$
\left(0.15 \gamma_{\mathrm{gw}} / \gamma_{\mathrm{ow}}\right) .
$$

where $\gamma$ : interfacial/surface tension

$$
\begin{aligned}
& \text { go }=\text { gas/oil phase } \\
& \text { ow }=\text { oil/water phase } \\
& \text { g/w }=\text { gas/water phase }
\end{aligned}
$$

If the value of the stability coefficient above is found to be negative, the foam is stable, otherwise is not stable. Various stability experiments from the work of different researchers are presented in Table 1. From the table, the stability criteria were used to assess the thermal stability of foam in contact with the oil.

\section{MECHANISMS OF EOR-FORMS GENERATION}

Snap-off mechanism In snap-off mechanism, which is regarded as a mechanical process, it involves the formation of collars in the pore throat by the wetting phase due to the movement of gas bubbles through the pore throat (Vasshus 2016). For snap-off to occur, a capillary pressure at the throat must be greater than the capillary pressure at the front of the interface. This could only occur if the ratio of the pore throat to the pore body is 1:2.67. Figure 1 describes the snap-off mechanism in the porous body. A snap-off mechanism has been reported as the dominant mechanism of foam generation (Morin et al. 2016; Vasshus 2016).

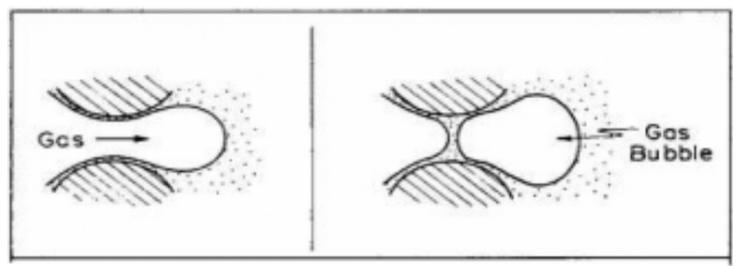

FIGURE 1. Schematic diagram of snap-off mechanism (Vanhuss 2016)

TABLE 1. Below presents various laboratory foam stability test predictions

\begin{tabular}{ccc}
\hline Stability criteria & Foam stability experiment & Reference \\
\hline $\mathrm{E}<0$ & Stable & Denkov et al. (2014) \\
$\mathrm{E}>0, \mathrm{~B}<0$ & Stable & Denkov et al. (2014) \\
$\mathrm{E}>0, \mathrm{~B}>0, \mathrm{~S}>0$ & Unstable & Simjoo et al. (2013), Jones et al. (2016), \\
$\mathrm{E}>0, \mathrm{~B}>0, \mathrm{~S}>0$ & unstable & Denkov et al. (2014) \\
$\mathrm{L}<0$ & Stable & Schramm and Novosad (1990) \\
$1<\mathrm{L}<5.5$ & Intermediate & \\
$\mathrm{L}>5.5$ & unstable & \\
\hline
\end{tabular}


Lamella Division mechanism Foam generation in this kind of mechanism requires pre-generated foam with bubble size larger than the pore body. A division of lamella occurs when lamella approaches the 'branch point' as seen in Figure 2.

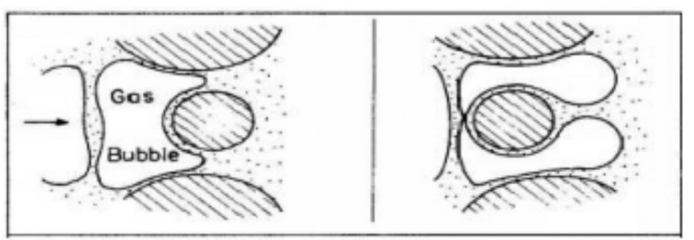

FIGURE 2. Schematic diagram of lamella division mechanism (Vanhuss 2016)

Leave behind mechanism Unlike snap-off and lamella division, this type of mechanism generates less stable and weaker foams, due to invasion of two or more gas fronts from different direction into a liquid saturated medium (Figure 3). These leads to generation of continuous gas bubbles which accumulate to form a parallel large number of lamellae and subsequently block the passage channels and result to dead-end pathways (Chen et al. 2004).

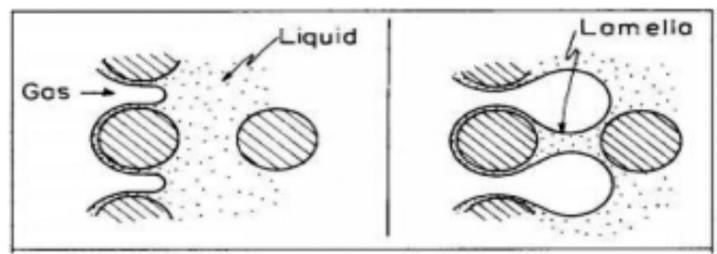

FIGURE 3. Schematic diagram of leave behind mechanism (Vanhuss 2016)

The examples of laboratory foams generated by the 3 mechanisms above using different types of foaming agents are presented in the Table 2.

\section{PROPERTIES OF EOR-FOAM}

EOR-foam quality Foam quality is the percent volume of a gas in foam bubbles under certain condition of pressure and temperature. In reservoir conditions, foam quality plays an important role because of foam mobility and foam resistance factors depend directly on the foam quality (Buchgraber et al.2012; Tyrode et al.2003). Approximately, foam qualities can reach up to $97 \%$, but most oilfield foams used for conformance improvement have quality typically in the range of 75 to $90 \%$ (Kalyanaraman et al. 2017). Apparent foams viscosity $\left(\mu_{\text {app }}\right)$ is one of the important properties that is used to assess the foam quality, which describe the relative foams stability. The $\mu_{\text {app }}$ is usually calculated according to (1) as follows;

$$
\mu_{\mathrm{app}}=\mathrm{k} \nabla \mathrm{P} /\left(\mathrm{u}_{1}+\mathrm{u}_{\mathrm{g}}\right)
$$

where $\mathrm{k}$ is the permeability $\left(\mathrm{m}^{2}\right) ; \mathrm{u}_{1}$ and $\mathrm{u}_{\mathrm{g}}$ are the liquid and gas superficial velocities respectively $(\mathrm{m} / \mathrm{s})$; and $\nabla \mathrm{P}$ is the pressure gradient $(\mathrm{Pa} / \mathrm{m})$ across the whole core.

Jones et al. (2016) studied the $\mu_{\text {app }}$ of six different foaming solutions (solution 1-6) to describe the foam quality as the parameter index for stability in the absence and presence of oil. The results are presented in Figure 4, which is a plot of $\mu_{\text {app }}$ as a function of the foam quality. From the figure, the authors reported that the curves appearing at the left represent low foam-quality regime because of the trapping and releasing of foam bubbles which affects the $\mu_{\text {app }}$ (which is dependent on the gas flow rate). However, at the right side of the curves, high foam-quality were observed due the foam behaviours were dominated by coalescence. They concluded that, presence of oil has less destabilizing effect on foams in the low foam-quality regime compared to the foams in the high foam-quality regime. Similar phenomena have been described in (Batôt et al. 2016; Zeng et al. 2016).

Derikvand and Riazi (2016) experimentally studied the qualities of four aqueous EOR-foams after modifying their viscosity using a cost effective polymer (carboxymethyl

TABLE 2. Laboratory generation of foams using different mechanisms

\begin{tabular}{|c|c|c|}
\hline Primary mechanisms & Type of foamers used & Reference \\
\hline \multirow[t]{3}{*}{ Snap-off } & $\begin{array}{l}\text { polydimethylsiloxane functionalized } \\
\text { with polyethylene glycol }\end{array}$ & Morin et al. (2016) \\
\hline & Alpha olefin sulphonate & Gauteplass et al. (2015) \\
\hline & Sodium laureth sulphate & Ferno et al. (2016) \\
\hline \multirow[t]{3}{*}{ Lamella division } & Sodium dodecyl sulphate & Géraud et al. (2017) \\
\hline & Sodium dodecyl sulphate & Géraud et al. (2016) \\
\hline & Alpha olefin sulphonate & Getrouw (2016) \\
\hline Leave behind* & $\begin{array}{l}\text { Sodium dodecyl benzene sulfonate and } \\
\text { Sodium dodecyl sulfate }\end{array}$ & Ransohoff and Radke (1988) \\
\hline
\end{tabular}




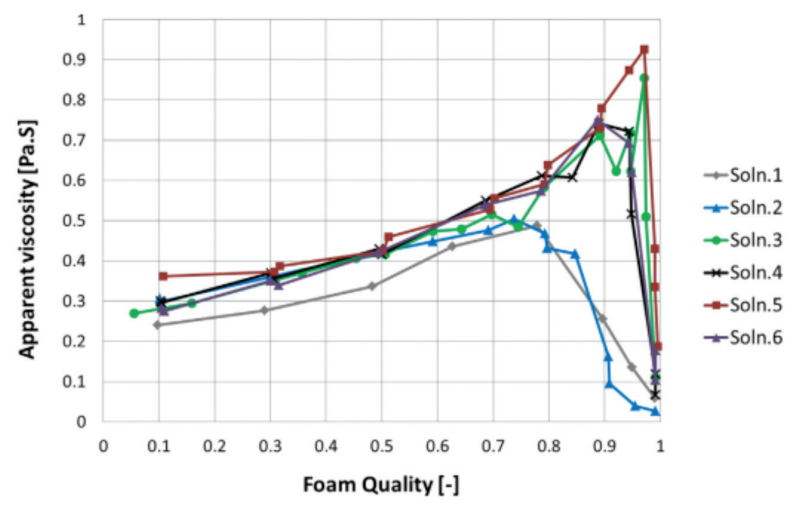

FIGURE 4. Apparent viscosity as a function of foam quality

cellulose gum). They found out that by increasing the polymer concentration, the foam viscosity increased and the foam quality was improved. Furthermore, they noticed that the foam quality is mainly dependant on the foam bubble, bubbles size, shape and viscosity of lamellae.

Similarly, Guo and Aryana (2016) determined the foam quality in terms of the foam density. Foam density is defined as the total number of bubbles formed per area. The authors noticed that, initially large number of bubbles were formed in the porous body and started to decay as a result of drainage and coalescence, thus resulting in fewer number of bubbles per area. They suggested that foam with low density reduction rate are more stable.

\section{EOR-FOAM HALF-LIFE}

Foam half-life is considered as the time taken by the generated foam to reach half of its initial volume upon decayed as described in Figure 5. It is not possible to count the number of bubbles, but the level of foam which decreases by the decadence of bubbles can be easily measured over time. In most of the EOR-foam studies, the foam half-life play important role to determine the foam quality and stability, thus, the longer the half-life the better the quality and the greater the stability.

The work of Jones et al. (2016) described the relationship between the foam half-life and IFT to measure the foam stability. They found that, foam stability assessment could not be established from the plot of foam

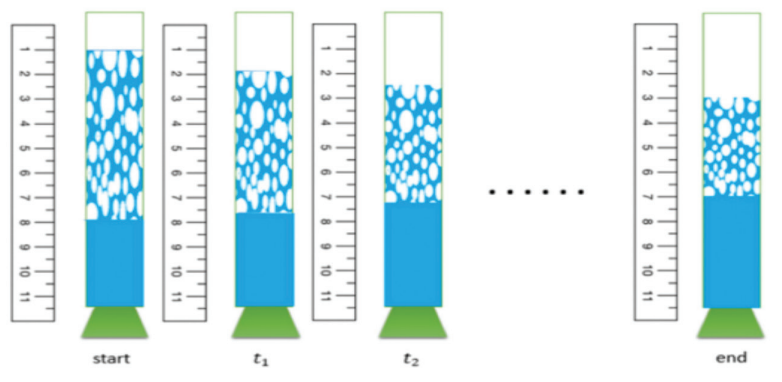

FIGURE 5. Schematic diagram to measure the foam half-life (Derikvand \& Riazi 2016) half-life against the IFT in the absence of oil. However, in the presence of oil, a clear relationship describing foam stability was observed. Their result indicated that the high IFT value between the oil and foam bubbles could prevent oil to enter the foam, thus the slower the decay rate. This conforms with the principle of the entry barrier stability coefficient (E) described in the Table 1.

Pu et al. (2017) also studied the relationship between the foaming concentration, surface tension, foam height and half-life. In their result (Figure 6), it can be observed that as the concentration of foaming agent increases, the foam height and foam half-life increased considerably, while the surface tension lowered. From the figure, it can also be observed that the IFT values are in direct relationship with the half-life value, hence this clearly supports the findings of Jones et al. (2016) above with respect to foam stability. Therefore, the plot of IFT and foam half-life could serve as a method to describe the foam quality and the stability.

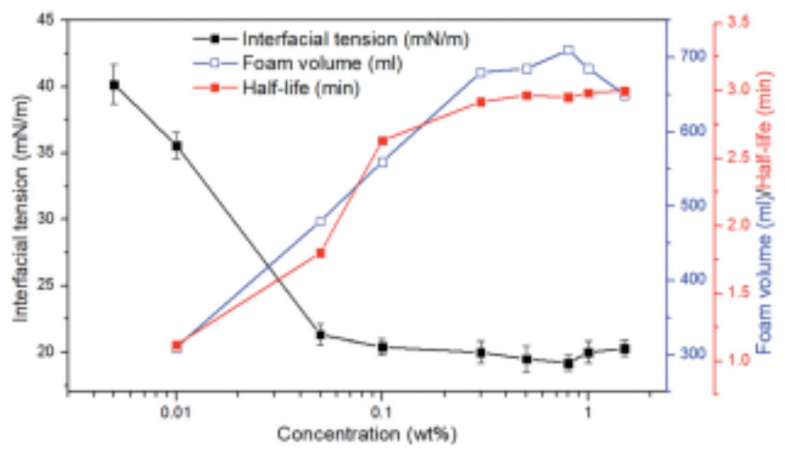

FIGURE 6. Foam volume, half-life and surface tension of CHSB at different concentrations

\section{EOR-FOAM BUBBLE SIZE AND DISTRIBUTION}

Foam bubble size and distribution constitute the foam texture, which is the main principle behind the foam mobility control. The foam with finer texture are believed to contain the smaller bubble size and has a higher resistance to flow than the bigger bubbles in the porous medium. However, dry foam with bigger bubbles in most cases have a higher viscosity than the wet foam with smaller bubbles. This statement conforms to the experimental work conducted by Osei-Bonsu et al. (2016), where the authors compared the apparent viscosities of the dry and wet EOR-foams with the bubble size. Though, the authors had pointed out that various thermodynamic parameters such as the foam generation mechanisms, bubble velocity, capillary pressure and injection rate affect the foam texture. Sun et al. (2015) has taken the research further to study the deformational stress the foam bubbles usually undergo while flowing in the porous media. The authors observed that foam bubbles generated from pure surfactant are more prone to deformation than those from the mixture of surfactant and additive as described in the Figure 7. 


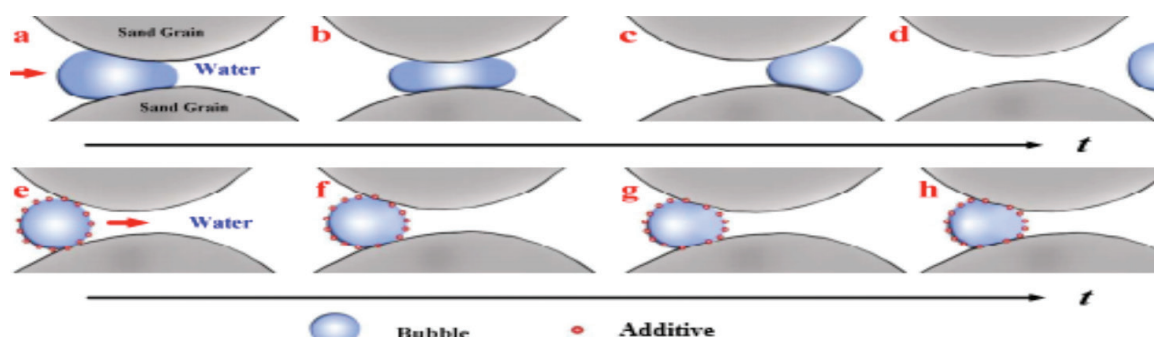

FIGURE 7. The different migration behaviors of surfactant foam (a to d) and surfactant/additive foam (e to h) in pore-throat

In addition to that, Wang et al. (2016) observed that pressure drop influenced the resistance of the bubble to deformation. That is, if the pressure drop is large, the resistance of the bubble to deformation would be stronger and the bubbles would encounter difficulties to pass between the grains.

\section{EOR-FOAM STABILITY IMPROVEMENT USING ADDITIVES}

In many literature reported to-date, the use of additive to improve surfactant properties and to obtain stable EORfoam is gaining popularity. Additives such as nanoparticles and polymers are essential to obtain an efficient and successful oil recovery. They serve as promoters to provide optimal conditions with respect to temperature, pressure and salinity (Fathi \& Ramirez 1984). Figure 8 typically describes an example of nanoparticles (silica nanoparticle) which has the ability to form a definite bond with the amphiphilic head of a foaming agent, thereby improving its thermal properties (Hesemann et al. 2014) as well as increase the oil recovery (Montoya et al. 2016).

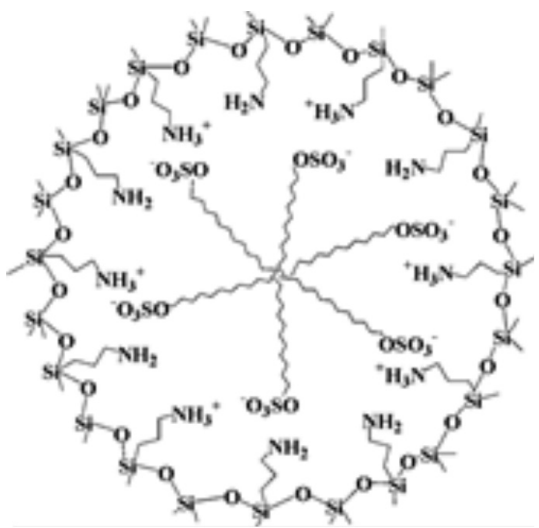

FIGURE 8. Effect of nanoparticles to improve surfactant properties

The composite of SDS/silica nanoparticles in the study of Sun et al. (2015) indicated that silica nanoparticles showed the ability to improve foams thermal stability by adsorbing at the surface of the liquid foam film.

Similarly, Al-Hadhrami and Blunt (2000) studied the effect of silica nanoparticles on wettability alteration and concluded that silica nanoparticles were a good agent to increase the hydrocarbon recovery rate which is also in agreement with the finding of Ahmadi and Shadizadeh (2013).

Worthen et al. (2014) reported that nanoparticles have greater adsorption energy, which enable them to be irreversibly adsorbed to the fluid/fluid interface and improved EOR-foam stability, even though, their studies were only limited to a $50^{\circ} \mathrm{C}$ experimental condition.

The polymers usually increase the foam viscosity, thus enhancing mobility control and improving the oil sweep (Levitt et al. 2006). Similarly, polymers have greater impacts to protect foaming agents against shear stress between rock pores (Figure 9(a)-9(c)). From Figure 9(a), it can be seen that the arrangement of surfactant micelles are destabilized due to shear stress in the rock pores, hence additional time is required for them to reunite and form micelles again. However, Figure 9(b) typically describes the elasticity of the polymer after subjected to shear and stress. Meanwhile, Figure 9(c), demonstrates that polymers as additive can assist and prevent surfactant from the effect of shear and stress in rock pores and ultimately enhanced oil recovery (Zhu et al. 2013).

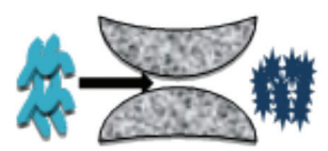

A

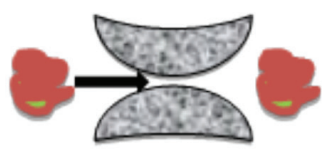

B

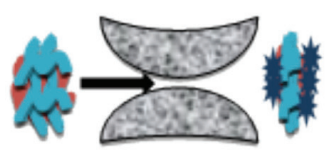

FIGURE 9. Graphical representation of the migration of surfactant (a), polymer (b) and surfactant and polymer mixture (c) through rock pores (Zhu et al. 2013)

Many core flood experiments show the benefits of adding polymers in the surfactant systems. Among the commonly employed polymers as additives include hydrolyzed polyacrylamide (HPAM), Xanthan gum and Schizopyllan (Levitt et al. 2006). 
Kapetas et al. (2016) studied the effect of high temperature in a sandstone porous medium using Alpha Olefin Sulphonate (AOS) as foaming agent. The authors provided significant information of foam generation between $20-80^{\circ} \mathrm{C}$. However, their findings showed that as the temperature reached $80^{\circ} \mathrm{C}$ in the core flood, the foams viscosity decreased by half, surface tension lowered and coalesced faster. They concluded that, with co-injection of foams, understanding foams behaviors and stability at elevated temperature is most important.

The studies of Zhao et al. (2015) provided other alternative means of maintaining foam stability up to $100^{\circ} \mathrm{C}$ using a polymer as additive.

Xue et al . (2016) in their investigation to stabilize EORfoam using a hybrid composite in a water-less hydraulic fracturing fluid had found out that the composite material consists of a polymer (HPAM), a surfactant (LAPB) and silica nanoparticles had the ability to stabilize the EOR-foam.

\section{UNSWEPT OIL IN THE LOW PERMEABLE RESERVOIR ZONES}

Various recovery enhancements have long been identified and applied in oil industries (Fathi \& Ramirez 1984). Most of the EOR processes have an increased recovery to about $30-40 \%$ or more of the original oil in place (OOIP) as compared with just $15-40 \%$ recovery through primary and secondary methods (Sakthipriya et al. 2015). Because of microscopic and macroscopic factors, about $60 \%$ of crude oil (OOIP) is left unswept in the reservoirs. The effects of wettability (rock-fluid interaction) and fluid/fluid interfacial or surface tension (IFT) attributed to microscopic factors, which resulted oil to remain in the rock pores unswept even at higher pressure (Meybodi et al. 2011). On the other hand, the macroscopic factor is due to reservoir rock permeability variations, where oil is easily displaced in high permeable regions, leaving unswept oil in the low permeable regions. Additionally, the negative capillary force in oil-wet formation is another factor of oil remaining in the rock pores unswept (Meybodi et al. 2011). To recover more oil, understanding sweep efficiencies of various fluids (foam) is crucial. Although various studies have demonstrated sweep efficiencies of some fluids yet it is difficult to maintain sweep conformance in reservoirs because of the rock heterogenity or anisotropy. The total sweep efficiency can be improved by increasing the capillary number as well as improving the mobility ratio in any EOR processes.

\section{SWEEP EFFICIENCY IMPROVEMENT}

Three most important methods to improve sweep efficiency have been developed and implemented, these are: The blockage of high permeability regions using polymers; Injection of IFT reduction agents (surfactants) which is micro phenomenon; and Injection of foam.

For the blockage of high permeability regions using polymers, Murata et al. (2010) in their water flooding experiment reported that the sweep efficiency could be improved by blocking high permeable zones in the reservoir using polymers, but found out that total sweep efficiency would be difficult to achieve because injected water apparently bypassed the blocked zones. In addition, Lalehrokh et al. (2008) observed that the crosslinking behaviour of blocking polymers was difficult to control, particularly at elevated reservoir temperature.

For the injection of IFT reducing agents, different types of EOR surfactant with respect to their compositions and concentrations have been developed and widely applied in various oil fields, however, surfactants were found to be highly sensitive to extreme reservoir conditions (temperature, pressure and salinity) and tend to be adsorbed or deposited on the reservoir rocks leading to economic loss (Fathi \& Ramirez 1984).

Lastly, the foam injection was found to be more effective than the first two cases because of the apparent low foam's viscosity. Foam control gas mobility and spontaneously diverts a gas to the lower permeable zones leading to the sweep conformance and enhanced recovery (Ferno et al. 2016). Detail information on diversion of gas by foam have been reported (Casteel \& Djabbarah 1988; Kovscek \& Bertin 2003; Llave et al. 1990; Nguyen et al. 2005; Zerhboub et al. 1994) and its visual evidence has been provided by Guteplass et al. (2015).

\section{EOR-FOAMS MOBILITY REDUCTION FACTOR}

To reduce the mobility of injected gases in the porous media, strong and stable foam is required, which can be generated at high oil saturations (Memon et al. 2016). This could be achieved by mobility reduction factor (MRF). The ratio of pressure drop as a result of injecting gas and liquid simultaneously through the porous body in the absence and presence of foaming solution is called MRF (Batôt et al. 2016). The MRF has the range value of 1-10,000 which is used as a correlation of foam reduction mobility. Under the reservoir conditions, if the MRF value is greater than 1 , it indicates the presence of foam in the porous body, while if it is less than 1 , the foam is absent in the porous body (Sheng 2013).

Memon et al. (2016) comparatively studied the MRF of foams from pure surfactant $(0.6 \% \mathrm{AOS})$ and surfactant blend of $(0.2 \%$ AOS $+0.2 \%$ TX-100) and $(0.6 \% \mathrm{AOS}+$ $0.6 \%$ LMDO) in the three different Barea core samples. The authors found out that due to the synergistic action of the blend's component, the foam generated by the surfactant blends demonstrated good MRF than the foam from the single surfactant slug and the maximum MRF was recorded by the surfactant blend of $0.6 \%$ AOS $+0.6 \%$ LMDO. Similarly, Etminan et al. (2016) experimentally proved the possibility to generate quality foam $(50 \%$ performance) using a steam gas and arylalkyl solfunate surfactant. In Figure 10, it can be seen that the authors showed the maximum MRF could reach more than 40 , which is sufficiently enough to ensure high degree of mobility control. Considering the mobility control effect of foam flooding, defining MRF with respect to different geological physicochemical properties of reservoir rocks 


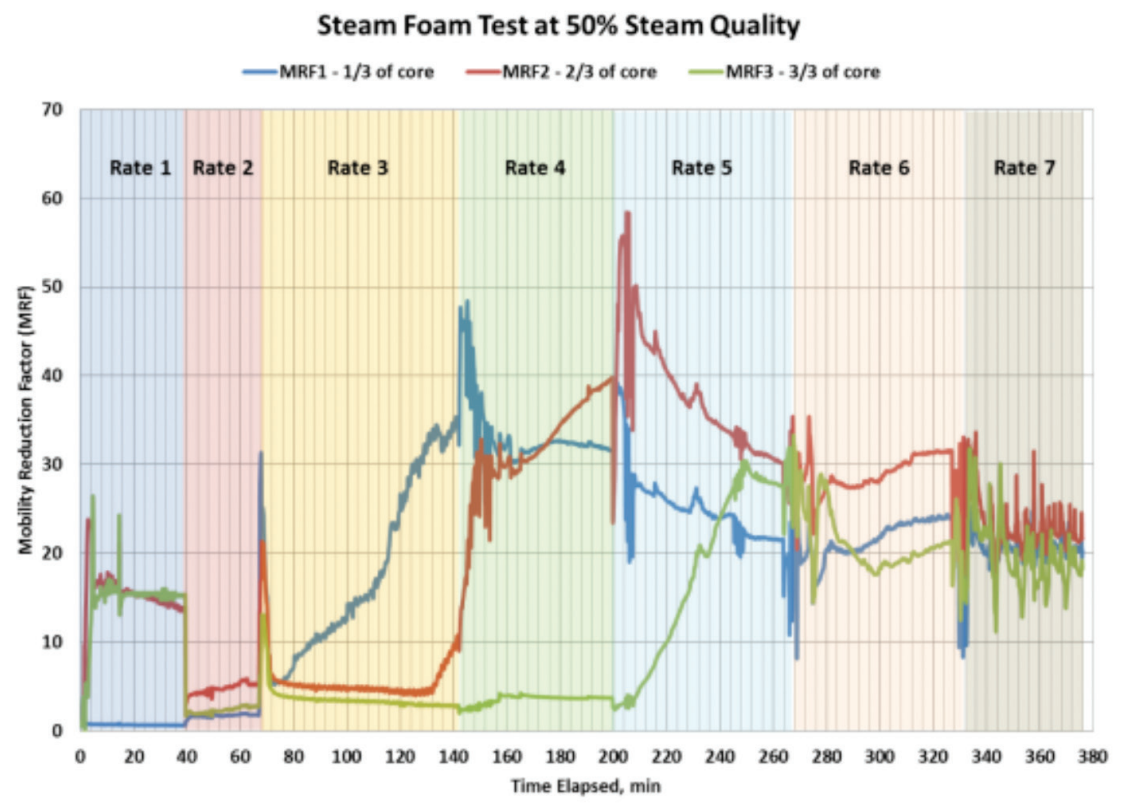

FIGURE 10. The MFR of different steam foam

is still an issue to be investigated to provide a consistent theory of MFR mechanisms in EOR.

Laboratory EOR-forms flooding (FAWAG) experiments Aghdam et al. (2013) studied the effect of EOR-foam in a water alternating gas method (WAG) and found out that injecting foams in a gas phase was more promising than in a water phase, however, the researchers noticed that, by increasing the surfactant concentration, recovery increased by a certain factor, but dropped after critical foam concentration was reached, hence suggested that for economic reasons, the critical foams concentration needs further investigations.

Tunio et al. (2012) compared the simultaneous water alternating gas (SWAG) with the FAWAG method using $2 \mathrm{wt}$. $\%$ surfactant in $30,000 \mathrm{ppm}$ brine solution for an enhanced recovery study. They discovered that FAWAG increased recovery tremendously after SWAG method had reached an optimal recovery factor. They concluded that the FAWAG method could improve oil recovery if applied after any WAG method. However, from the understanding of authors of this paper, the critical concentration of foaming agents plays vital role, thus, different concentrations of foaming agents should have been thoroughly investigated to see the effects of the surfactant/brine solution at a different concentration range (not just 2 wt. \% surfactant in 30,000 ppm brine solution) so as to provide reliable scientific data in the selection of a surfactant/brine solution system in any foam assisted flooding techniques.

The recovery experimental studies on different EOR techniques (water, hot water, $\mathrm{N}_{2}, \mathrm{CO}_{2}$, associated gas and WAG $\left(\mathrm{CO}_{2}\right.$ /water, $\mathrm{N}_{2} /$ water, associated gas/water and associated gas/hot water)) were conducted by Ahmadi et al. (2015). Their investigation showed that WAG (associated gas/hot water) in particular had a recovery of $88.5 \%$ heavy oil and was selected as the best method based on their studies. Despite the fact that the FAWAG method is the most effective recovery method as reported in many open literature, yet the scope of their research did not focus on FAWAG which could have added value in their comparative studies. Furthermore, the selection of associated gas/hot water as the favored method for WAG seems not conclusive. Reason being that, if WAG (associated gas/water) and WAG $\left(\mathrm{CO}_{2} /\right.$ water) methods in the same study could recover 83 and $80 \%$ heavy oils, respectively, by considering the slight differences between the two recovery values above, what would be the EOR if the WAG $\left(\mathrm{CO}_{2} /\right.$ hot water $)$ method had been further investigated? Therefore, further research is recommended to investigate the effect of $\mathrm{CO}_{2} /$ hot water and hot foams (FAWAG) in oil recovery.

The review of Shabib et al. (2014) highlighted the advantages of (FAWAG) method over other EOR methods and reported that a minimal amount of laboratory work were carried out on foam generation in heterogeneous porous media which consequently had led to lack of adequate understanding of the foaming mechanisms.

\section{FIELD APPLICATION OF EOR-FOAM AND CHALLENGES}

As discussed in this paper, the biggest detrimental effect to foam property is the extreme reservoir conditions which has attracted the interest of researchers within the industry and academia in putting more efforts to bringing the lasting solutions for foam instability. However, apart from this, the transition of foam flooding from laboratory to pilot and to that of field application is not clearly understood and specified. These are attributed to offshore application, economic and technical issues as well as lack of good engineering technology for EOR-foam flooding plant. However, it should be noted that despite such challenges, various field-foam application had been successfully executed in the past years. Some examples are given in 
TABLE 3. EOR-foam application in the oilfield (Hou et al. 2012; Li et al. 2009; Sheng 2013)

\begin{tabular}{|c|c|c|c|c|}
\hline Field name & $\begin{array}{l}\text { Year of } \\
\text { project }\end{array}$ & Challenges to overcome & Foam flooding advantage & $\begin{array}{l}\text { Challenges due to foam } \\
\text { flooding }\end{array}$ \\
\hline Daqin & 2012 & $\begin{array}{l}\text { High water cut, poor sweep } \\
\text { efficiency and severe heterogeneity }\end{array}$ & $\begin{array}{l}\text { Mobility control and } \\
\text { blockage of high thief } \\
\text { zones }\end{array}$ & No \\
\hline Shengali Tuo11 & 2004 & High water cut and gas override & $\begin{array}{l}\text { Water cut dropped and oil } \\
\text { production increased }\end{array}$ & No \\
\hline Snorre & 1996 & Premature gas breakthrough & $\begin{array}{l}50 \% \text { reduction in GOR for } \\
22 \text { months }\end{array}$ & $\begin{array}{l}\text { Yes: Difficult to evaluate } \\
\text { foam performance due to } \\
\text { geological complexity }\end{array}$ \\
\hline $\begin{array}{l}\text { East Mallet Unit, } \\
\text { Texas }\end{array}$ & 1994 & Gas channeling and production & $\begin{array}{c}\text { Reduction of gas } \\
\text { channeling and production }\end{array}$ & $\begin{array}{l}\text { Yes: (operational } \\
\text { problem with } \\
\text { coinjection) }\end{array}$ \\
\hline $\begin{array}{l}\text { East Vaccum } \\
\text { grayburg, Mexico }\end{array}$ & 1993 & $\begin{array}{l}\text { The reservoir pressure dropped } \\
\text { below MMP and strange } \\
\text { breakthrough patterns evolved }\end{array}$ & Indepth diversion of a gas & $\begin{array}{l}\text { Yes: Economical } \\
\text { (chemical and } \\
\text { operational costs) }\end{array}$ \\
\hline $\begin{array}{c}\text { North Ward-Ester, } \\
\text { Texas }\end{array}$ & 1991 & $\begin{array}{l}\text { Vertical conformance poor sweep } \\
\text { and low oil recovery }\end{array}$ & $\begin{array}{l}\text { Diversion of } \mathrm{CO}_{2} \text { from } \\
\text { thief zone to unswept } \\
\text { region and improved oil } \\
\text { production }\end{array}$ & No \\
\hline
\end{tabular}

Table 3. The arising problems/challenges that prompted the application of foam in such fields are also presented in the table.

\section{CONCLUSION}

This paper presented and discussed the present status, stability, performance and application of EOR-foam from the perspective of laboratory scale to field application. It analyses and recommended areas of the knowledge gaps which require further research for successful field application.

\section{ACKNOWLEDGEMENTS}

The authors would like to express their sincere and honest gratitude to the Enhance Oil Recovery Mission Oriented Research Group of Universiti Teknologi PETRONAS and Exploration, Production and Technical Department of PETRONAS, Malaysia for studentship support and financing the project (Grant No. EPTD T1.3), respectively.

\section{REFERENCES}

Aghdam, K.A., Moghaddas, J. \& Moradi, B. 2013. An investigation of the effect of using foam in WAG injection in an Iranian oil reservoir. Petroleum Science and Technology 31(21): 2228-2236.

Ahmadi, M.A. \& Sheng, J. 2016. Performance improvement of ionic surfactant flooding in carbonate rock samples by use of nanoparticles. Petroleum Science 13(4): 725-736.

Ahmadi, M.A. \& Shadizadeh, S.R. 2013. Induced effect of adding nano silica on adsorption of a natural surfactant onto sandstone rock: Experimental and theoretical study. Journal of Petroleum Science and Engineering 112: 239-247.
Ahmadi, Y., Eshraghi, S.E., Bahrami, P., Hasanbeygi, M., Kazemzadeh, Y. \& Vahedian, A. 2015. Comprehensive Water-Alternating-Gas (WAG) injection study to evaluate the most effective method based on heavy oil recovery and asphaltene precipitation tests. Journal of Petroleum Science and Engineering 133: 123-129.

Al-Hadhrami, H.S. \& Blunt, M.J. 2000. Thermally induced wettability alteration to improve oil recovery in fractured reservoirs. SPE/DOE Improved Oil Recovery Symposium. Society of Petroleum Engineers. pp. 1-9.

Alvarado, V. \& Manrique, E. 2010. Enhanced oil recovery: An update review. Energies 3(9): 1529-1575.

Buchgraber, M., Castanier, L.M. \& Kovscek, A.R. 2012. Microvisual investigation of foam flow in ideal fractures: Role of fracture aperture and surface roughness. SPE Annual Technical Conference and Exhibition. Society of Petroleum Engineers.

Batôt, G., Fleury, M. \& Nabzar, L. 2016. Study of $\mathrm{CO}_{2}$ foam performance in a CCS context. The 30th International Symposium of the Society of Core Analysts-Snowmass.

Casteel, J.F. \& Djabbarah, N.F. 1988. Sweep improvement in $\mathrm{CO}_{2}$ flooding by use of foaming agents. SPE Res. Eng. 3(4): 1186-1192.

Chen, M., Yortsos, Y.C. \& Rossen, W.R. 2004. A pore-network study of the mechanisms of foam generation. SPE Annual Technical Conference and Exhibition. Society of Petroleum Engineers.

Denkov, J.N.D., Marinova, K.G. \& Tcholakova, S.S. 2014. Mechanistic understanding of the modes of action of foam control agents. Adv. Colloid Interface Sci. 206: 57-67.

Derikvand, Z. \& Riazi, M. 2016. Experimental investigation of a novel foam formulation to improve foam quality. Journal of Molecular Liquids 224(Part B): 1311-1318.

Etminan, S.R., Goldman, J. \& Wassmuth, F. 2016. Determination of optimal conditions for addition of foam to steam for conformance control. In SPE EOR Conference at Oil and Gas West Asia. Society of Petroleum Engineers. 
Farzaneh, S.A. \& Sohrabi, M. 2013. A review of the status of foam application in enhanced oil recovery. EAGE Annual Conference \& Exhibition incorporating SPE Europec. Society of Petroleum Engineers.

Fathi, Z. \& Ramirez, W.F. 1984. Optimal injection policies for enhanced oil recovery: Part 2 - surfactant flooding. SPE paper 12814. SPE Journal 24(3): 331-341.

Ferno, M.A., Gauteplass, J., Pancharoen, M., Haugen, Å., Graue, A., Kovscek, A.R. \& Hirasaki, G. 2016. Experimental study of foam generation, sweep efficiency, and flow in a fracture network. SPE Journal 21(4). DOI. https://doi. org/10.2118/170840-PA.

Gauteplass, J., Chaudhary, K., Kovscek, A.R. \& Fernø, M.A. 2015. Pore-level foam generation and flow for mobility control in fractured systems. Colloids and Surfaces A: Physicochemical and Engineering Aspects 468: 184-192.

Géraud, B., Méheust, Y., Cantat, I. \& Dollet, B. 2017. Lamella division in a foam flowing through a two-dimensional porous medium: A model fragmentation process. Physical Review Letters 118(9): 098003.

Géraud, B., Jones, S.A., Cantat, I., Dollet, B. \& Méheust, Y. 2016. The flow of a foam in a two-dimensional porous medium. Water Resources Research 52(2): 773-790.

Getrouw, N.A.S. 2016. The static and dynamic behaviour of foam in a model porous media. Master of Science. Applied Earth Sciences at the Delft University of Technology. pp.16-106 (Unpublished).

Guo, F. \& Aryana, S. 2016. An experimental investigation of nanoparticle-stabilized $\mathrm{CO}_{2}$ foam used in enhanced oil recovery. Fuel 186: 430-442.

Hamza, M.F., Sinnathambi, C.M. \& Merican, Z.A. 2016. Recent advancement of hybrid materials used in chemical enhanced oil recovery. 29th Symposium of Malaysian Chemical Engineering Conference, Miri, Sarawak, Malaysia.

Hesemann, P., Nguyen, T.P. \& Hankari, S.E. 2014. Precursor mediated synthesis of nanostructured silicas: From precursorsurfactant ion pairs to structured materials. Materials 7(4): 2978-3001.

Hou, J., Zhang, Y.H., Lu, N., Yao, C.J. \& Lei, G.L. 2016. A new method for evaluating the injection effect of chemical flooding. Petroleum Science 13: 496-506.

Hou, Q., Zhu, Y., Luo, Y. \& Weng, R. 2012. Studies on foam flooding EOR technique for daqing reservoirs after polymer flooding. In SPE Improved Oil Recovery Symposium. Society of Petroleum Engineers.

Jones, S.A., van der Bent, V., Farajzadeh, R., Rossen, W.R. \& Vincent-Bonnieu, S. 2016. Surfactant screening for foam EOR: Correlation between bulk and core flood experiments. Colloids and Surfaces A: Physicochemical and Engineering Aspects 500: 166-176.

Kalyanaraman, N., Arnold, C., Gupta, A., Tsau, J.S. \& Ghahfarokhi, R.B. 2017. Stability improvement of CO2 foam for enhanced oil-recovery applications using polyelectrolytes and polyelectrolyte complex nanoparticles. Journal of Applied Polymer Science 134(6). DOI: 10.1002/app.44491.

Kapetas, L., Bonnieu, S.V., Danelis, S., Rossen, W.R., Farajzadeh, R., Eftekhari, A.A. \& Bahrim, R.K. 2016. Effect of temperature on foam flow in porous media. Journal of Industrial and Engineering Chemistry 36: 229-237.

Kovscek, A.R. \& Bertin, H.J. 2003. Foam mobility in heterogeneous porous media II: Experimental observations. Transport in Porous Media 52(1): 37-49.
Lalehrokh, F., Bryant, S.L., Huh, C. \& Sharma, M.M. 2008. Application of $\mathrm{pH}$-triggered polymers in fractured reservoirs to increase sweep efficiency. SPE Symposium on Improved Oil Recovery. Society of Petroleum Engineers. pp. 1-8.

Levitt, D., Jackson, A., Heinson, C., Britton, L.N., Malik, T., Dwarakanath, V. \& Pope, G.A. 2006. Identification and evaluation of high-performance EOR surfactants. SPE/DOE Symposium on Improved Oil Recovery. Society of Petroleum Engineers. pp. 1-11.

Li, Z.Q., Song, X.W., Wang, Q.W., Zhang, L., Guo, P. \& Li, X.L. 2009. Enhanced foam flooding pilot test in chengdong of shengli oilfield: Laboratory experiment and field performance. International Petroleum Technology Conference. DOI: https://doi.org/10.2523/IPTC-13575-MS.

Llave, F.M., Chung, F.H., Louvier, R.W. \& Hudgins, D.A. 1990. Foams as mobility control agents for oil recovery by gas displacement. SPE/DOE Enhanced Oil Recovery Symposium. Society of Petroleum Engineers. pp. 1-14.

Memon, M.K., Shuker, M.T. \& Elraies, K.A. 2016. Study of blended surfactants to generate stable foam in presence of crude oil for gas mobility control. Journal of Petroleum Exploration and Production Technology 7(1): 77-85.

Meybodi, H.E., Kharrat, R. \& Wang, X. 2011. Study of microscopic and macroscopic displacement behaviors of polymer solution in water-wet and oil-wet media. Transport in Porous Media 89(1): 97-120.

Montoya, T., Argel, B.L., Nassar, N.N., Franco, C.A. \& Cortés, F.B. 2016. Kinetics and mechanisms of the catalytic thermal cracking of asphaltenes adsorbed on supported nanoparticles. Petroleum Science 13(3): 561-571.

Morin, B., Liu, Y., Alvarado, V. \& Oakey, J. 2016. A microfluidic flow focusing platform to screen the evolution of crude oilbrine interfacial elasticity. Lab on a Chip 16(16): 3074-3081.

Murata, S., Ashida, A., Okabe, H., Fukahori, D. \& Ishida, T. 2010. Sweep efficiency improvement by blocking already swept high permeable zones in reservoir with biodegradable polymer gel. The IEA EOR 2010 31st Annual Workshop and Symposium, Aberdeen, Scotland, October 18-20.

Nagy, R., Sallai, R., Bartha, L., \& Vágó, Á. 2015. Selection method of surfactants for chemical enhanced oil recovery. Advances in Chemical Engineering and Science 5: 121-128.

Nangacovié, H.L.M. 2012. Application of WAG and SWAG Injection Techniques in Norne E-Segment. Department of Petroleum Engineering and Applied Geophysics, Norwegian University of Science and Technology. p. 91.

Nezhad, E.H., Ghorbani, M., Zeinalkhani, M. \& Heidari, A. 2013. DNA encapsulation in an anionic reverse micellar solution of dioctyl sodium sulfosuccinate. Physical Chemistry 3(1): 7-10.

Nguyen, Q.P., Currie, P.K. \& Zitha, P.L.J. 2005. Effect of crossflowon foam-induced diversion in layered formations. SPE J. 10(1): 54-65.

Osei-Bonsu, K., Shokri, N. \& Grassia, P. 2016. Fundamental investigation of foam flow in a liquid-filled Hele-Shaw cell. Journal of Colloid and Interface Science 462: 288-296.

Pu, W., Wei, P., Sun, L. \& Wang, S. 2017. Stability, CO2 sensitivity, oil tolerance and displacement efficiency of polymer enhanced foam. RSC Advances 7(11): 6251-6258.

Ransohoff, T.C. \& Radke, C.J. 1988. Mechanisms of foam generation in glass-bead packs. Journal of Reservoir Engineering of Society of Petroleum Engineers 3: 573-585. http://dx.doi.org/10.2118/15441-pa.

Sakthipriya, N., Doble, M. \& Sangwai, J.S. 2015. Enhanced oil recovery techniques for Indian reservoirs, In Petroleum 
Geosciences: Indian Contexts, edited by Mukherjee, S. Springer Geology. Springer, Cham. pp. 237-269.

Salehi, M.M., Safarzadeh, M.A., Sahraei, E. \& Nejad, S.A.T. 2014. Comparison of oil removal in surfactant alternating gas with water alternating gas, water flooding and gas flooding in secondary oil recovery process. Journal of Petroleum Science and Engineering 120: 86-93.

Schramm, L.L. 2000. Surfactants: Fundamentals and Applications in the Petroleum Industry. Cambrige: Cambridge University Press.

Schramm, L.L. \& Novosad, J.J. 1990. Micro-visualization of foam interaction with a crude oil. Colloids Surf. 46(1): 21-43.

Shabib-Asl, A., Ayoub, M.A., Alta'ee, A.F., Saaid, I.B.M. \& Valentim, P.P.J. 2014. Comprehensive review of foam application during foam assisted water alternating gas (FAWAG) method. Research Journal of Applied Sciences, Engineering and Technology 8(17): 1896-1904.

Shedid, S.A. 2015. Experimental investigation of alkaline/ surfactant/polymer (ASP) flooding in low permeability heterogeneous carbonate reservoirs. SPE North Africa Technical Conference and Exhibition. Society of Petroleum Engineers. pp. 1-16.

Sheng, J. 2013. Enhanced Oil Recovery Field Case Studies. Gulf Professional Publishing.

Simjoo, M., Rezaei, T., Andrianov, A. \& Zitha, P.L.J. 2013. Foam stability in the presence of oil: Effect of surfactant concentration and oil type. Colloids and Surf. A: Physicochem. and Eng. Asp. 438: 148-158.

Sun, L., Pu, W., Xin, J., Wei, P., Wang, B., Li, Y. \& Yuan, C. 2015. High temperature and oil tolerance of surfactant foam/ polymer-surfactant foam. RSCAdvances 5(30): 23410-23418.

Sun, Q., Li, Z., Wang, J., Li, S., Jiang, L. \& Zhang, C. 2015. Properties of multi-phase foam and its flow behavior in porous media. RSC Advances 5(83): 67676-67689.

Talebian, S.H., Tan, I.M., Sagir, M. \& Muhammad, M. 2015. Static and dynamic foam/oil interactions: Potential of CO2philic surfactants as mobility control agents. Journal of Petroleum Science and Engineering 135: 118-126.

Touray, S. 2013. Effect of water alternating gas injection on ultimate oil recovery. Master of Engineering. Dalhousie University. p. 25 (Unpublished).

Tunio, S.Q., Chandio, T.A. \& Memon, M.K. 2012. Comparative study of FAWAG and SWAG as an effective EOR technique for a Malaysian field. Research Journal of Applied Sciences, Engineering and Technology 4(6): 645-648.

Tunio, S.Q., Tunio, A.H., Ghirano, N.A. \& El-Adawy, Z.M. 2011. Comparison of different enhanced oil recovery techniques for better oil productivity. International Journal of Applied Science and Technology 1(5): 143-153.

Tyrode, E., Pizzino, A. \& Rojas, O.J. 2003. Foamability and foam stability at high pressures and temperatures. I. Instrument validation. Review of Scientific Instruments 74(5): 2925-2932.

Tzimas, E., Georgakaki, A., Cortes, C.G. \& Peteves, S.D. 2005. Enhanced oil recovery using carbon dioxide in the European energy system. EUR - Scientific and Technical Research Reports 21895(6).

Vasshus, S.S. 2016. Experimental study of foam generation and flow in carbonate fracture systems. Master Thesis. University of Bergen (Unpublished).
Verma, M.K. 2015. Fundamentals of carbon dioxide-enhanced oil recovery (CO2-EOR). A supporting document of the assessment methodology for hydrocarbon recovery using CO2-EOR associated with carbon sequestration: U.S. Geological Survey Open-File Report 2015-1071,19. http:// dx.doi.org/10.3133/ofr20151071.

Wang, Y., Ge, J., Zhang, W., Zhang, G., Lin, Y. \& Song, K. 2016. Surface property and enhanced oil recovery study of foam aqueous dispersions comprised of surfactants-organic acids-nanoparticles. RSC Advances 6(114): 113478-113486.

Worthen, A.J., Parikh, P.S., Chen, Y., Bryant, S.L., Huh, C. \& Johnston, K.P. 2014. Carbon dioxide-in-water foams stabilized with a mixture of nanoparticles and surfactant for CO2 storage and utilization applications. Energy Procedia 63: 7929-7938.

Xue, Z., Worthen, A., Qajar, A., Robert, I., Bryant, S.L., Huh, C. \& Johnston, K.P. 2016. Viscosity and stability of ultra-high internal phase CO2-in-water foams stabilized with surfactants and nanoparticles with or without polyelectrolytes. Journal of Colloid and Interface Science 461: 383-395.

Zeng, Y., Muthuswamy, A., Ma, K., Wang, L., Farajzadeh, R., Puerto, M., Vincent-Bonnieu, S., Akbar Eftekhari, A., Wang, Y., Da, C., Joyce, J.C., Biswal, S.L. \& Hirasaki, G.J. 2016. Insights on foam transport from a texture-implicit localequilibrium model with an improved parameter estimation algorithm. Industrial \& Engineering Chemistry Research 55(28): 7819-7829.

Zerhboub, M., Touboul,E., Ben-Naceur,K.\& Thomas, R.L. 1994. Matrix acidizing: A novel approach to foam diversion. SPE Production \& Facilities 9(2): 121-126.

Zhao, G., Dai, C., Zhang, Y., Chen, A., Yan, Z. \& Zhao, M. 2015. Enhanced foam stability by adding comb polymer gel for in-depth profile control in high temperature reservoirs. Colloids and Surfaces A: Physicochemical and Engineering Aspects 482: 115-124.

Zhu, D., Zhang, J., Han, Y., Wang, H. \& Feng, Y. 2013. Laboratory study on the potential EOR use of HPAM/VES hybrid in high-temperature and high-salinity oil reservoirs. Journal of Chemistry 2013: Article ID. 927519.

Center of Research in Enhanced Oil Recovery (COREOR) Universiti Teknologi Petronas

32610 Bandar Seri Iskandar, Perak Darul Ridzuan Malaysia

Fundamental and Applied Sciences Department Universiti Teknologi Petronas 32610 Bandar Seri Iskandar, Perak Darul Ridzuan Malaysia

*Corresponding author; email: chandram1457@gmail.com

Received: 17 January 2017

Accepted: 8 April 2017 